\title{
Depression in older people living in residential homes
}

\section{Introduction}

There is a large body of published research relating to depression in residential homes for older people (also called long-term-care homes, and including both nursing homes and hostels) (Ames 1990; 1993; Seitz et al., 2010; Snowdon and Purandare, 2010; Snowdon, 2010). However, despite increased detection and more frequent treatment in recent years, depression remains a significant problem for many older people living in such settings. This guest editorial summarizes current knowledge about prevalence, etiology, detection and screening, treatment and outcomes of depression in residential homes and concludes with a summary of key issues requiring urgent future action.

\section{Residential care homes for older people}

The provision of residential homes for older people varies markedly around the world and there is no universal agreed definition for these facilities, which include both hostels and nursing homes (also known in some places as low-level and high-level care) and are sometimes referred to as long-term care facilities (Ribbe et al., 1997; Snowdon and Purandare, 2010). Nursing homes can be defined as residential facilities offering 24-hour nursing care, while hostels can be considered as facilities that offer personal care and social involvement for people who can no longer manage at home, but need no more nursing care than could be provided by visiting nurses (Ribbe et al., 1997). Using these definitions, 3.63\% of Americans aged over 65 years were in nursing homes in 2004 (National Nursing Homes Survey, 2004), while the UK provision of all residential home beds was 450,000 in 2000 , but is expected to rise to 1.1 million by 2051 (Wittenberg et al., 2004 ). Australia has a total population of 22 million (just over one-third that of the UK and less than two-thirds of the US state of California) with a lower percentage aged over 65 than most European countries, but 162,300 Australians were living in mainstream residential care services in mid-2009, an increase of 2050 residents over the previous year (Australian Institute of Health and Welfare, 2010).

\section{Depression: definitions and diagnosis}

The term "depression" can refer to both depressive disorders and depressive symptoms. In modern research and clinical practice, diagnoses of depressive disorders are made most often using either the criteria of the World Health Organization's International Classification of Diseases, 10th revision (ICD-10; World Health Organization, 1992) or the American Psychiatric Association's Diagnostic and Statistical Manual, 4th edition (DSM-IV; American Psychiatric Association, 1994).

The ICD-10 mandates diagnosis of a depressive episode when four or more of the following ten symptoms are present most of the day, most days for at least two weeks in the absence of another disorder (e.g. hypothyroidism, schizophrenia, dementia, etc.) that could better account for the symptoms: low mood, loss of interest and enjoyment (anhedonia), disturbed sleep, decreased or increased weight or appetite, loss of energy, psychomotor slowing, poor concentration, feelings of guilt or self reproach, recurrent thoughts of death or suicide, and loss of confidence (World Health Organization, 1992). In the DSM-IV, five of nine of the above symptoms (excluding loss of confidence) must be present for the same two-week period for a diagnosis of major depressive disorder to be confirmed (American Psychiatric Association, 1994). Both systems require that the symptoms cause clinically significant stress or impairment in social, occupational or other important areas of functioning.

Milder forms of depression that do not fulfill criteria for ICD-10 depressive episode or DSM-IV major depression are common, often comorbid with other illnesses or recent bereavement, and frequently are of substantial clinical significance. These are sometimes referred to as minor depression, dysthymic disorder (if present chronically for two years) or depressive symptoms (Ames, 1993).

\section{Prevalence and incidence of depression in residential care homes for older people}

Prevalence of depression in residential care homes is high, ranging from $4 \%$ to $25 \%$ for major depressive disorder and $29 \%$ to $82 \%$ for minor 
depression or the presence of depressive symptoms (Seitz et al., 2010). A recent review by Seitz and colleagues (2010), published in this journal, examined 74 studies on prevalence of psychiatric disorders in nursing homes, including 26 on depression. Dementia, depression and anxiety were the most common psychiatric disorders affecting older people in long-term care. A range of instruments was used to assess depression in the 26 studies cited, making it difficult to determine prevalence more precisely than the wide ranges cited above. The Geriatric Depression Scale (GDS) was used in 12 studies but three different versions were used with a range of cut-off points (Seitz et al., 2010). See Table 1 for a summary of selected prevalence studies.

In most countries prevalence of depression in residential homes is substantially higher than among community-dwelling older people, particularly in the case of major depression. Junginger and colleagues (1993) found that $21 \%$ of their sample living in nursing homes in the USA had major depression compared with $10 \%$ of communitydwelling older people. Similarly, a British study found a $9.3 \%$ prevalence of major depression in community-dwelling older people, compared with $27.1 \%$ in nursing homes (McDougall et al., 2007). However, in the latter study, there was a similar prevalence of minor depression in community-dwelling and nursing home residents (26.7\% compared with $22.6 \%$ ).

One apparently contradictory Korean study found greater prevalence of depression in older people living in their own homes, with $39.5 \%$ showing symptoms of depression compared with $24.0 \%$ of nursing home residents (Chung, 2008). In this study, nursing home residents had significantly higher function in instrumental and personal activities of daily living (ADL), fewer children and more friends than community-dwelling older people. Functional ADL status is associated with depression (see Etiology section below) so this may explain this finding, which is out of line with most published comparative research. In addition, Korean cultural expectations of filial piety probably mean that older people with children are more likely to be cared for at home, regardless of their functional dependence.

The incidence of depression appears to be approximately $5-6 \%$ for new cases of both major and minor depression over a 6-12 month period (Parmelee et al., 1992b; Smalbrugge et al., 2006a). Progression from minor to major depression may be higher, with one study finding $16.2 \%$ of people with minor depression progressing to major depression over a 12-month period (Parmelee et al., 1992b).

\section{Etiology of depression}

A number of factors contribute to depression in residential care homes, but no single factor can be considered the sole cause of depressive symptoms in most residents. Nor does any single factor (or combination of factors) have the same effect on different individual residents. The evidence indicates that variables including the types of homes; the education and training levels of staff; the personality, attitudes and coping strategies of residents themselves; resident health status (psychological health, physical disability/comorbidity and levels of function and dependence); social support; and length of time in care all have the potential to influence symptom expression.

\section{Physical and mental health}

In a review article one of the present authors (Ames, 1993) noted that physical disability was strongly associated with depression, but emphasized the need for further studies to identify and define other risk factors. Medical comorbidities and functional impairment have emerged as important risk factors in a number of subsequent studies (Henderson et al., 1994; Hyer et al., 2005; Segal, 2005; Watson et al., 2006). Persistent pain also has been identified as a major risk factor, affecting both mood and quality of life (Cuijpers and Lammeren, 1999; Asghari et al., 2006). Medications for a number of comorbid conditions (e.g. anti-hypertensive/cardiac drugs; treatment for Parkinson's disease, antineoplastic drugs and certain antibiotics) may also cause depression or produce depressive symptoms (Garavaglia, 2004).

The medical conditions listed by Hyer et al. (2005) include those whose symptoms may overlap with those of depression, and indicate a high correlation between dementia and depression. This correlation is reported in a number of other studies (Gruber-Baldini et al., 2005; Sheehan et al., 2007), though it is difficult to determine cause and effect. A history of previous depression is one of the best predictors of manifest depression in residents of care homes for older people (Payne et al., 2002), and better cognitive functioning increases levels of risk of depression when associated with loss of physical function and capacity to live independently (Jones et al., 2003; Tsai et al., 2005). Jones et al. (2003) also identified Parkinson's disease and heart disease as risk factors, although medication for these conditions may be implicated too (Garavaglia, 2004).

Other studies have noted relationships between depression and loss of perception, as in hearing loss (Eisses et al., 2004) and uncorrected refractive error 
Table 1. Selected studies on prevalence of depression in residential homes

\begin{tabular}{|c|c|c|c|c|c|}
\hline $\begin{array}{l}\text { AUTHOR/S, } \\
\text { YEAR }\end{array}$ & $\begin{array}{l}\text { COUNTRY/CITY, } \\
\text { AREA/SETTING }\end{array}$ & METHOD & $\begin{array}{l}\text { FINDINGS AND } \\
\text { REMARKS }\end{array}$ & $\begin{array}{l}\text { SAMPLE } \\
\text { SIZE }\end{array}$ & $\begin{array}{l}\text { DIAGNOSTIC } \\
\text { INSTRUMENT AND } \\
\text { CRITERIA }\end{array}$ \\
\hline Seitz et al., 2010 & $\begin{array}{l}\text { Canada } \\
\text { Long-term care (LTC) }\end{array}$ & $\begin{array}{l}\text { Review of } 74 \text { studies } \\
\text { examining the prevalence of } \\
\text { psychiatric disorders and } \\
\text { psychological symptoms in } \\
\text { LTC populations. } 26 \\
\text { examined depression. } \\
\text { The } 26 \text { depression studies } \\
\text { included } 9 \text { from North } \\
\text { America, } 7 \text { from Europe, } 1 \\
\text { from middle East, } 4 \text { from } \\
\text { Aust/NZ, } 1 \text { from Africa and } \\
4 \text { from Asia. }\end{array}$ & $\begin{array}{l}\text { Most studies involved few } \\
\text { LTCs and were in developed } \\
\text { countries. Prevalence of a } \\
\text { major depressive disorder } \\
\text { (MD) varied between } \\
4-25 \% \text { and depressive } \\
\text { symptoms were reported in } \\
29-82 \% \text { of residents. }\end{array}$ & $\begin{array}{l}1 \text { to } 951 \text { nursing homes (in } 26 \\
\text { depression studies) }\end{array}$ & $\begin{array}{l}\text { GDS (12 studies) } \\
\text { DSM-III-R or DSM-IV } \\
\quad \text { ( } 6 \text { studies) } \\
\text { CSDD ( } 3 \text { studies) } \\
\text { CES-D ( } 1 \text { study) } \\
\text { Other ( } 6 \text { studies) }\end{array}$ \\
\hline $\begin{array}{l}\text { Sandberg et al., } \\
\quad 1998\end{array}$ & $\begin{array}{l}\text { Sweden } \\
\text { Nursing home } \\
\text { Old people's homes } \\
\text { Medical care districts }\end{array}$ & $\begin{array}{l}\text { Cross sectional study, single } \\
\text { survey assessment }\end{array}$ & $\begin{array}{l}41 \% \text { depressed mood. } \\
\text { Depressed mood most } \\
\text { common in home medical } \\
\text { care }(48.5 \%) \text { and nursing } \\
\text { homes }(47.5 \%) .\end{array}$ & $\begin{array}{l}717 \text { hospital patients and care } \\
\text { home residents } \\
3 \text { nursing homes } \\
5 \text { old people's homes } \\
2 \text { home medical care districts }\end{array}$ & $\begin{array}{l}\text { Organic Brain Syndrome } \\
\text { Scale }\end{array}$ \\
\hline $\begin{array}{l}\text { Achterberg et al., } \\
2006\end{array}$ & $\begin{array}{l}\text { Netherlands } \\
\text { Nursing homes }\end{array}$ & $\begin{array}{l}\text { Residents assessed within } 10 \\
\text { days of admission }\end{array}$ & $\begin{array}{l}\text { Overall prevalence of } \\
\text { depressive symptoms was } \\
26.9 \% \text {, higher in residents } \\
\text { admitted from their own } \\
\text { homes }(34.3 \%) \text { than those } \\
\text { admitted from hospital } \\
(19.7 \%) \mathrm{p}=0.002\end{array}$ & $\begin{array}{l}562 \text { residents } \\
65 \text { nursing homes }\end{array}$ & $\begin{array}{l}\text { 7-item MDS Depression } \\
\text { Rating Scale (DRS) } \\
\text { Cut off of } \geq 3\end{array}$ \\
\hline Chung, 2008 & $\begin{array}{l}\text { Korea } \\
\text { Nursing homes } \\
\text { Community }\end{array}$ & Analysis of 2 data sets & $\begin{array}{l}39.5 \% \text { of community-dwelling } \\
\text { older people showed } \\
\text { symptoms of depression } \\
\text { compared with } 24.0 \% \text { of } \\
\text { nursing home residents }\end{array}$ & $\begin{array}{l}307 \text { care home residents } \\
166 \text { community-dwelling } \\
\text { residents }\end{array}$ & GDS- 15 cut off $\geq 8$ \\
\hline
\end{tabular}


Table 1. Continued

\begin{tabular}{|c|c|c|c|c|}
\hline $\begin{array}{l}\text { AUTHOR/s, } \\
\text { YEAR }\end{array}$ & $\begin{array}{l}\text { COUNTRY/CITY, } \\
\text { AREA/SETTING }\end{array}$ & METHOD & $\begin{array}{l}\text { FINDINGS AND } \\
\text { REMARKS }\end{array}$ & $\begin{array}{l}\text { SAMPLE } \\
\text { SIZE }\end{array}$ \\
\hline $\begin{array}{l}\text { Kerber et al., } \\
\quad 2005\end{array}$ & $\begin{array}{l}\text { Iowa, USA } \\
\text { Nursing homes }\end{array}$ & $\begin{array}{l}\text { Secondary analysis of data } \\
\text { collected from } 279 \\
\text { randomly selected nursing } \\
\text { home residents in rural } \\
\text { Iowa, scoring }>15 \text { on the } \\
\text { MMSE }\end{array}$ & $\begin{array}{l}\text { Prevalence based on the GDS } \\
\geq 6 \text { was } 37.3 \% \text {. Overall } \\
\text { prevalence according to any } \\
\text { of the } 3 \text { measures was } \\
67.1 \%\end{array}$ & 279 care home residents \\
\hline Lin et al., 2007 & $\begin{array}{l}\text { Taiwan } \\
\text { Nursing homes }\end{array}$ & $\begin{array}{l}\text { Face to face interviews } \\
\text { conducted using CES-D, } \\
\text { social support scale, chronic } \\
\text { condition checklist and } \\
\text { socio-demographic } \\
\text { inventory }\end{array}$ & $\begin{array}{l}81.8 \% \text { of residents identified } \\
\text { as depressed }\end{array}$ & $\begin{array}{l}138 \text { residents } \\
8 \text { nursing homes }\end{array}$ \\
\hline $\begin{array}{l}\text { Mozley et al., } \\
2000\end{array}$ & $\begin{array}{l}\text { Manchester, UK } \\
\text { Nursing homes }\end{array}$ & $\begin{array}{l}\text { Newly admitted residents } \\
\text { screened for cognitive } \\
\text { impairment, depression and } \\
\text { dependency. }\end{array}$ & $\begin{array}{l}\text { Just under } 45 \% \text { identified as } \\
\text { depressed cases }\end{array}$ & $\begin{array}{l}248 \text { residents } \\
30 \text { nursing or residential care } \\
\text { homes }\end{array}$ \\
\hline $\begin{array}{l}\text { Brodaty et al., } \\
2001\end{array}$ & $\begin{array}{l}\text { Australia } \\
\text { Nursing homes }\end{array}$ & $\begin{array}{l}\text { Residents surveyed using the } \\
\text { BEHAVE AD observer } \\
\text { rating scale. }\end{array}$ & $\begin{array}{l}\text { Depressed mood in } 42 \% \text { of } \\
\text { residents } \\
\text { Behavioral disturbances } \\
\text { frequently associated with } \\
\text { psychosis and/or depression }\end{array}$ & $\begin{array}{l}647 \text { residents } \\
11 \text { nursing homes }\end{array}$ \\
\hline $\begin{array}{l}\text { McDougall } \\
\text { et al., } 2007\end{array}$ & $\begin{array}{l}\text { England and Wales } \\
\text { Nursing homes } \\
\text { Community }\end{array}$ & $\begin{array}{l}\text { Stratified random sub-sample } \\
\text { of } 2,640 \text { participants from } \\
\text { the Medical Research } \\
\text { Council Cognitive Function } \\
\text { and Ageing study (MRC } \\
\text { CFAS) received Geriatric } \\
\text { Mental State examination of } \\
\text { whom } 340 \text { were living in } \\
\text { institutions. }\end{array}$ & $\begin{array}{l}\text { Prevalence of depression (case } \\
\text { level - of a severity that } \\
\text { warrants treatment) in } \\
\text { institutions was } 27.1 \% \\
\text { compared to } 9.3 \% \text { in those } \\
\text { living at home. } \\
\text { Sub-clinical depression } 26.7 \% \\
\text { of people living in } \\
\text { institutions and } 22.6 \% \text { of } \\
\text { those living at home. }\end{array}$ & 340 residents \\
\hline
\end{tabular}

DIAGNOSTIC

INSTRUMENT AND CRITERIA

MDS Depression quality indicator (sad mood plus 2 or more symptoms of functional depression), GDS-15 $\geq 6$, primary care provider (PCP) depression diagnosis from the residents' charts (diagnosis assigned by nurse or physician)

CES-D cut off $\geq 16$ out of 60.

GDS-15 cut off point of $5 / 6$

Answered positive to item 21 depressed mood and/or $\geq 1$ on BEHAVE $\mathrm{AD}$ affective disturbance sub-scale and/or chart diagnosis of depression

GMS schedule analyzed by AGECAT included anyone with a diagnosis of depression even if secondary to dementia. 


\begin{tabular}{|c|c|c|c|c|c|}
\hline $\begin{array}{l}\text { Smallbrugge } \\
\text { et al., 2006a }\end{array}$ & $\begin{array}{l}\text { Netherlands } \\
\text { Nursing homes }\end{array}$ & $\begin{array}{l}\text { Residents assessed with the } \\
\text { GDS-30 at baseline and } \\
\text { 6-month follow-up. }\end{array}$ & $\begin{array}{l}\text { Prevalence of depressive } \\
\text { symptoms decreased from } \\
41.3 \% \text { to } 28.8 \% \text { at } 6 \text {-month } \\
\text { follow-up. } \\
\text { Onset of depression among } \\
\text { those not depressed at } \\
\text { baseline was } 4.7 \% \text { and the } \\
\text { rate of persistence was } \\
63.3 \% \text {. Persistence was } \\
\text { more common among those } \\
\text { with higher GDS scores } \\
(18-30) \text { at baseline }\end{array}$ & 350 residents & GDS- 30 cut off $>10$ \\
\hline $\begin{array}{l}\text { Junginger et al., } \\
1993\end{array}$ & $\begin{array}{l}\text { Louisiana, USA } \\
\text { Nursing homes } \\
\text { Community }\end{array}$ & $\begin{array}{l}\text { Participants assessed with the } \\
\text { Structured Clinical } \\
\text { Interview for DSM-III } \\
\text { (SCID) (and for nursing } \\
\text { home residents, diagnoses } \\
\text { recorded on charts) }\end{array}$ & $\begin{array}{l}\text { 25/100 NH residents were } \\
\text { diagnosed with mood } \\
\text { disorder ( } 21 \% \text { with major } \\
\text { depression) and } 5 / 50 \\
\text { community residents (all } 5 \\
\text { with major depression). }\end{array}$ & $\begin{array}{l}100 \text { care home residents } \\
50 \text { community-dwelling } \\
\text { residents }\end{array}$ & $\begin{array}{l}\text { SCID (and for nursing } \\
\text { home residents, } \\
\text { diagnoses recorded on } \\
\text { charts) }\end{array}$ \\
\hline $\begin{array}{l}\text { Parmalee et al., } \\
\text { 1992a }\end{array}$ & $\begin{array}{l}\text { Pennsylvania, USA } \\
\text { Nursing homes } \\
\text { Congregate apartments }\end{array}$ & $\begin{array}{l}\text { One-year longitudinal study to } \\
\text { examine incidence and } \\
\text { persistence of depression } \\
\text { among nursing home and } \\
\text { congregate apartment } \\
\text { residents. }\end{array}$ & $\begin{array}{l}\text { 15.7\% of } 868 \text { persons } \\
\text { interviewed at Time } 1 \\
\text { displayed possible major } \\
\text { depression and } 16.5 \% \\
\text { displayed minor depressive } \\
\text { symptoms. } \\
\text { At Time } 2 \text { the incidence of } \\
\text { major depression for } \\
\text { non-depressives (at Time } 1 \text { ) } \\
\text { was } 5.6 \% \text { and } 6.6 \% \text { for } \\
\text { minor depression. } \\
\text { More than } 40 \% \text { of possible } \\
\text { major depressives at Time } 1 \\
\text { showed no remission of } \\
\text { symptoms but more than } \\
\text { half of T1 minor depressives } \\
\text { showed no depression at T2, } \\
\text { however } 16.2 \% \text { had } \\
\text { progressed to major } \\
\text { depression. }\end{array}$ & 868 residents & $\begin{array}{l}\text { GDS-20 and DSM-III-R. } \\
\text { Major depression was } \\
\text { defined as the presence } \\
\text { of a significant } \\
\text { dysphoria or a score of } \\
\geq 11 \text { on the GDS, plus } \\
4 \text { additional depressive } \\
\text { symptoms as } \\
\text { enumerated by the } \\
\text { DSM-IIIR. } \\
\text { Dysphoria without the } 4 \\
\text { additional symptoms } \\
\text { was labeled minor } \\
\text { depression. For those } \\
\text { who failed to complete } \\
\text { the additional checklist } \\
\text { data, GDS scores of } 17 \\
\text { for major depression } \\
\text { and } 11 \text { for minor } \\
\text { depression were used. }\end{array}$ \\
\hline
\end{tabular}


Table 1. Continued

\begin{tabular}{|c|c|c|c|c|c|}
\hline $\begin{array}{l}\text { AUTHOR/S, } \\
\text { YEAR }\end{array}$ & $\begin{array}{l}\text { COUNTRY/CITY, } \\
\text { AREA/SETTING }\end{array}$ & METHOD & $\begin{array}{l}\text { FINDINGS AND } \\
\text { REMARKS }\end{array}$ & $\begin{array}{l}\text { SAMPLE } \\
\text { SIZE }\end{array}$ & $\begin{array}{l}\text { DIAGNOSTIC } \\
\text { INSTRUMENT AND } \\
\text { CRITERIA }\end{array}$ \\
\hline $\begin{array}{l}\text { Teresi et al., } \\
2001\end{array}$ & $\begin{array}{l}\text { USA } \\
\text { Nursing homes }\end{array}$ & $\begin{array}{l}\text { Random sample of } 319 \mathrm{NH} \\
\text { residents drawn from a } \\
\text { random sample of } 6 \\
\text { downstate New York } \\
\text { nursing homes evaluated } \\
\text { psychiatrically for } \\
\text { depression. } \\
\text { Sample of nurse aides, nurses } \\
\text { and social workers } \\
\text { also assessed the same } \\
\text { sample. }\end{array}$ & $\begin{array}{l}14.4 \% \text { of residents had major } \\
\text { and } 16.8 \% \text { minor } \\
\text { depression and the } \\
\text { prevalence of depressive } \\
\text { symptomatology, including } \\
\text { possible depression was } \\
44.2 \% \text {. }\end{array}$ & $\begin{array}{l}319 \text { residents } \\
6 \text { nursing homes }\end{array}$ & $\begin{array}{l}\text { Psychiatrists used the } \\
\text { CSDD, the Feeling } \\
\text { Tone Questionnaire, } \\
\text { the HDRS and the } \\
\text { SCID personality } \\
\text { disorders scale. }\end{array}$ \\
\hline $\begin{array}{l}\text { Chow et al., } \\
2004\end{array}$ & $\begin{array}{l}\text { Hong Kong } \\
\text { Nursing homes }\end{array}$ & $\begin{array}{l}\text { One-off assessment using the } \\
\text { Chinese version of the } \\
\text { GDS-SF }\end{array}$ & $\begin{array}{l}\text { Significant depressive } \\
\text { symptoms detected in } 29 \% \\
\text { of subjects }\end{array}$ & 245 residents & $\begin{array}{l}\geq 8 \text { on GDS-15 for major } \\
\text { depression }\end{array}$ \\
\hline
\end{tabular}

AGECAT = Automated Geriatric Examination for Computer Assisted Taxonomy; CES-D = Centre for Epidemiological Studies Depression; CSDD = Cornell Scale for Depression in Dementia; DRS = Depression Rating Scale; GDS = Geriatric Depressive Scale; GDS-SF = Geriatric Depressive Scale-Short Edition; GMS = Geriatric Mental State; HDRS = Hamilton Depression Rating Scale; MDS = Minimum Data Set; MMSE = Mini-Mental State Examination; SCID = Structured Clinical Interview for DSM-III 
affecting vision (Owsley et al., 2007). A further study identified a relationship between depression and malnutrition (Smoliner et al., 2009) though no clear pathway of causality was apparent.

\section{Individual personality, social history, attitudes and coping strategies}

Loss, a major factor in admission into residential care homes, is strongly associated with depression. Personal loss encompasses grief over the death of loved ones, loss of home, pets, social support and close friends; loss of function and control over the body; loss of independence and autonomy; and loss of the familiar (Hyer et al., 2005; Pot et al., 2005; Zeiss, 2005; Choi et al., 2008). An important factor is the loss of control over one's own destiny (Krach et al., 1996). Personal coping styles and attitudes are important in explaining why some people are more negatively affected than others by loss and the presence of death. Cataldo (1994) found "nonhardiness and health-limiting death attitudes" to be reliable predictors of depression, and staff in another study identified social withdrawal (related to despair, loss, grief, loneliness and isolation) as a key indicator of depression (Choi et al., 2009). Lack of assertiveness is likely to lower defenses against institutional risk factors (Segal, 2005). Higher education levels also correlate with greater likelihood of being depressed in long-term care (Eisses et al., 2004), especially when associated with loss of mobility, function and independence.

\section{Residential care home environments}

Institutional factors that may contribute to depression include loss of privacy and frustration over shared rooms, noise, institutional furniture and odors, lack of stimulating social programs, lack of close relationships, high turnover rate of staff with little training and many cultural and educational differences, and other frustrations of living in close quarters with strangers under an institutional regime (Hyer et al., 2005; Choi et al., 2008). The medicalized environment of residential home settings and lack of alternative approaches to care have also been identified as depression risk factors (Garavaglia, 2004; Zeiss, 2005), as has the constant presence of death (Cataldo, 1994).

\section{Length of time in care}

The evidence suggests that the influence of length of time in care is different for cognitively impaired residents, and more likely to be a negative for the well-being of those without cognitive impairment (Stout et al., 1993; Pot et al., 2005). Many residents admitted with dementia have undiagnosed depression (Sheehan et al., 2007), which is likely to improve if diagnosed and treated on and after admission (Masand, 1995; Payne et al., 2002). For residents with better cognitive function, the risk of becoming depressed increases with length of stay and an increased sense of hopelessness over health status and lack of autonomy (Jones et al., 2003; Hyer et al., 2005; Pot et al., 2005; Tsai et al., 2005).

\section{Detection of depression}

Despite high prevalence, depression is still underdetected in residential care homes (Davidson et al., 2006). The Geriatric Depression Scale (GDS), the Cornell Scale for Depression in Dementia (CSDD), and, in the USA, the mood subscale of the Minimum Data Set (MDS) are the most frequently used tools for screening and detection.

\section{Screening and detection instruments}

The GDS has been widely used in residential care homes and several shorter versions have been developed, the most popular being the 15-item version. The original 30 -item version (using a cutoff point of $\geq 11$ ) has good psychometric properties. Gerety and colleagues (1994) found moderate to substantial agreement with the DSM-III-R criterion standard for major depression and recommended its use in residential care homes, as both a case finding and severity instrument. Jongenelis and colleagues (2005) found the GDS-30 to have sensitivity of $96.3 \%$ for major depression and $85.1 \%$ for minor depression compared with psychiatric interview and DSM-IV criteria. The 15-item version is generally preferred over the original as it is quicker to complete (6 minutes versus 12) and has good psychometric properties compared with the original version (McCurren, 2002) and with DSM criteria (Gerety et al., 1994). A five-item version of the GDS is also effective as a screening tool for depression in cognitively intact older adults, with 0.94 sensitivity and 0.81 specificity compared with an evaluation by a geriatrician (Rinaldi et al., 2003). As the GDS relies on self-report, there is debate as to whether it is suitable for use with people with mild to moderate dementia. A recent study comparing the GDS15 with DSM-IV-TR criteria in people with and without dementia found adequate specificity and sensitivity, suggesting that it may be an appropriate instrument for use in these populations (Lach et al., 2010).

The CSDD has been extensively evaluated for use in residential care homes. The CSDD covers five areas: mood related signs, behavioral disturbances, physical signs, cyclic functioning and ideational disturbances. It takes approximately 30 minutes to complete: 20 minutes with a carer (or other 
informant) and 10 minutes with the older person. It is reliable, valid and sensitive, and can differentiate the entire range of severity, including mild to no depression (Alexopoulos et al., 1988). Its limitations are that it takes 30 minutes to complete, requires trained personnel, does not correlate well with a psychiatrist's assessment, and is not always accurate in people with advanced dementia (de Bellis and Williams, 2008). Despite these limitations, de Bellis and Williams concluded that it is the most comprehensive depression screening tool for older people with and without dementia, making it suitable for use in residential care homes. The main advantage of the tool is its use of multiple sources of information. Koritsas et al. (2006) suggest that routine use of the CSDD in residential care homes could improve doctor, nurse and personal carer communication, as personal care staff can be informants in the assessment of depression. Poor communication between professionals has been identified as a barrier to identification of depression in residential care homes (Brown et al., 2006).

Seven items from the mandated MDS from the Resident Assessment Instrument in the USA have been validated for use as a depression screening tool known as the MDS Depression Rating Scale (DRS) (Burrows et al., 2000). In the original study the DRS compared favorably with the GDS-15 and the DRS has since been found to have adequate sensitivity and specificity and to be able to be reliably administered via self-report to residents with a MMSE score $\geq 12$ (Ruckdeschel et al., 2004). However, other studies have found poor correlation between the DRS and the GDS-15 (McCurren, 2002; Jones et al., 2004; Meeks, 2004). This is probably due to the use of different information sources, as the GDS relies on self-report and the DRS is an observer-rated instrument. It may also be that the tools are measuring different elements of depression. One study found that the MDS identified greater depression among people with cognitive impairment and the GDS-15 identified more depression in people with better cognitive functioning (Jones et al., 2004). Meeks (2004) did not recommend the use of the MDS DRS as a screening tool for residential care homes because of its poor correlation and poor psychometric properties compared with the GDS.

A single screening question "Do you feel that your life is empty?" was trialed as a screening tool for depression in residential care homes in London and compared with the CSDD. A "yes" response indicated that the resident was twice as likely to have depression and a "no" response meant that there was a $75 \%$ chance that they did not have depression. Half of the study sample $(n=209)$ scored less than 15 on the Mini-Mental State Examination
(MMSE) but there was no difference in sensitivity or specificity for the screening question for different levels of cognitive impairment. Watson et al. (2009) trialed five strategies for depression screening in residential aged care. The best strategy was a twoitem version of the Patient Health Questionnaire (PHQ-2) with a sensitivity of 0.80 and specificity of 0.75 as it was brief and easy to administer.

\section{Under-detection}

Nurses and personal care staff should be well placed to detect depression because of their close involvement with residents, but most are not very good at recognizing the symptoms of depression (Leo et al., 2002; Ayalon et al., 2008). There is a poor relationship between resident and nurse CSDD ratings (Burrows, 1995). Brühl and colleagues (2007) found the GDS detected $50 \%$ more depression than did nurses. Nurses recognized depression in only $55 \%$ of residents diagnosed via a psychiatric interview using DSMIV criteria and they detected depression in $40 \%$ of residents not diagnosed as depressed. In the study by Watson and colleagues (2009) mentioned above, measures completed by care staff (modified version of the CSDD and a one-item screen) failed to detect depression adequately. A UK study conducted by Bagley and colleagues (2000) found that only $15-27 \%$ of 308 newly admitted residents with depression were identified as depressed by staff (GDS compared with staff informant interviews). They concluded that more education was needed, as less than $2 \%$ of staff in their study had received in-service training on depression in older people. Ayalon et al. (2008) found that paraprofessional staff working in residential care homes were more likely to view depression as a normal phenomenon, had less accurate beliefs about signs and symptoms and were less familiar with effectiveness of treatments for depression than nurses, social workers and activity staff. Education should be targeted to meet the needs of this group, as they provide the bulk of the care to residents.

\section{Education}

A number of studies have investigated the impact of education on detection and treatment of depression in residential care homes (McCabe et al., 2008). In an American study investigating nursing home physicians' beliefs about how well they can detect and treat depression, excellent training (versus good, fair, poor or none) and the use of screening tools were associated with better recognition and treatment skills, and practice guideline awareness was associated with greater self-reported treatment competency (Banazak et al., 1999). A single 
education session for general practitioners (GPs) on late life depression was associated with improved GP recognition of depression in nursing home residents in an Australian study (Davidson et al., 2006). In another Australian study, staff education was one component of a successful multifactorial intervention for improving detection and treatment of depression in residential care homes (LlewellynJones et al., 1999). Dutch nursing home staff randomized to a 4-hour training session on recognition of depression through observation of ADLs (using the Behavior Rating Scale for Psychogeriatric Inpatients) were better able to recognize depression than those in the control group. The ability to identify residents who were not depressed did not differ between groups. The use of video-based training also improves nursing staff's ability to detect mood symptoms in nursing home residents (Wood et al., 2002). Having a mandated screening tool also improves recognition and initiation of treatment for depression in residential care homes (Boyle et al., 2004).

\section{Treatment and management of depression in residential homes}

Assessment is an essential pre-requisite to treatment (Morris, 2008) and may identify factors that could cause or contribute to depression, such as drug reaction, medical illness (Morris, 2008), pain (Asghari et al., 2006), or environmental factors (Choi et al., 2008). Addressing such issues may alleviate depressive symptoms.

\section{Treatment approaches}

The main approaches in treatment of depression anywhere at any age can be divided into biological (e.g. antidepressants and electroconvulsive therapy (ECT)), psychological (e.g. cognitive behavior therapy) and social (e.g. recreational activities). Treatments may be used singly or in combination depending on circumstances. Table 2 displays a summary of representative treatment studies in residential care homes.

Antidepressants are the most common treatment for depressed residents (Brown et al., 2002; Carlson and Snowden, 2007). There is evidence that antidepressants are effective for treating depression, in particular, major depression in care home residents (Rovner and Katz, 1993; Snowden et al., 2003). It is suggested that antidepressants should be included in the first-line treatment for residents with major depression (American Geriatrics Society and American Association for Geriatric Psychiatry, 2003). Several different classes of antidepressant are available (Baldwin, 2008) and the choice of medication should be based on the side effect profile, potential interactions with other medications and the resident's comorbid illnesses (Masand, 1995; Rosen et al., 2000; Kallenbach and Rigler, 2006). Antidepressants should be started at a low dose and be increased slowly (Snowdon et al., 1996; Bell and Goss, 2001; American Geriatrics Society and American Association for Geriatric Psychiatry, 2003; Kallenbach and Rigler, 2006). ECT is usually administered in hospital and is reserved for severe depression, but because it works quickly ECT should be considered as the firstline treatment for residents at high risk of suicide (Kallenbach and Rigler, 2006).

Numerous psychological approaches are appropriate to treat depression in residential care homes. These include behavior therapy (Meeks and Depp, 2003; Meeks et al., 2008; 2009), cognitive therapy (Zerhusen et al., 1991; Tsai et al., 2008), cognitive behavior therapy (CBT) (Hyer et al., 2008), and life review approaches (Chao et al., 2006; Plastow, 2006). Social interventions include various types of recreational activities (Snowden et al., 2003), e.g. therapeutic biking programs (Fitzsimmons, 2001; Buettner and Fitzsimmons, 2002). Most of the studies cited above reported significant beneficial effects and some review papers have concluded that psychosocial approaches are effective in treating depression, in particular minor depression, in residential care homes (Snowden et al., 2003; Hyer et al., 2005). Consistently, it is suggested that non-pharmacological methods should be considered as first-line treatment for residents with minor depression (American Geriatrics Society and American Association for Geriatric Psychiatry, 2003). It is important to note that many of these approaches were delivered in a group format (Bharucha et al., 2006). Group therapy is a more practical and cost-effective strategy in the residential home environment (Carlson and Snowden, 2007). Individual psychotherapy is not available in most residential care homes (Snowden et al., 2003) due to a shortage of trained psychotherapists, cost, and, in many countries, a lack of any tradition of psychotherapists working in residential care homes.

There is also some evidence that other approaches, such as staff training (Glaister and Blair, 2008), changes in health service model (Snowden et al., 2003) and residential home environment (Bell and Goss, 2001) might also be effective in reducing residents' depressive symptoms.

It seems likely that combining medical and psychosocial approaches would be the best way to manage depression in residential care homes (McCurren et al., 1999; American Geriatrics Society and American Association for Geriatric 
Table 2. Representative studies of treatment for depression in residential homes for the elderly

\begin{tabular}{|c|c|c|c|c|c|c|c|c|}
\hline $\begin{array}{l}\text { AUTHOR, } \\
\text { YEAR }\end{array}$ & COUNTRY & SETTING & MEASURES & DESIGN & $\mathrm{N}$ & TREATMENT (S) & LENGTH & RESULT \\
\hline $\begin{array}{l}\text { Buettner et al., } \\
\quad 2002\end{array}$ & USA & $\begin{array}{l}\text { Skilled long-term } \\
\text { care facility and } \\
\text { assisted living } \\
\text { centre }\end{array}$ & $\begin{array}{l}\text { MMSE, } 15 \text { item } \\
\text { GDS, CMAI }\end{array}$ & RCT & 70 & $\begin{array}{l}\text { Therapeutic biking in } \\
\text { residents with } \\
\text { dementia vs. control }\end{array}$ & $\begin{array}{l}12 \text { weeks, including } \\
\text { phase } 1 \text { ( } 2 \text { week of } \\
\text { intense treatment }) \text { and } \\
\text { phase } 2(10 \text { week of } \\
\text { maintenance })\end{array}$ & $\begin{array}{l}\text { Mean GDS decreased } \\
\text { significantly from } 8.00 \\
\text { to } 4.48 \text { after phase } 1 \\
\text { and } 3.14 \text { after phase } 2 \\
\text { in the treatment group; } \\
\text { no changes in the } \\
\text { control group }\end{array}$ \\
\hline $\begin{array}{l}\text { Cernin et al., } \\
\quad 2009\end{array}$ & USA & $\begin{array}{l}\text { Senior assisted } \\
\text { living community }\end{array}$ & $\begin{array}{l}\text { GDS, MLDT, } \\
\text { PES-AD, Global } \\
\text { mood }\end{array}$ & Cross over & 15 & $\begin{array}{l}\text { Individual psychotherapy } \\
\text { (pleasant event } \\
\text { activities); immediate } \\
\text { treatment vs. wait-list } \\
\text { treatment }\end{array}$ & $\begin{array}{r}12 \text { weeks, } 330-\text { min } \\
\text { sessions per week }\end{array}$ & $\begin{array}{l}\text { Significant decrease in } \\
\text { mean GDS (from } \\
12.33 \text { to } 10.66 \text { ) in the } \\
\text { whole treatment } \\
\text { sample }\end{array}$ \\
\hline
\end{tabular}




\begin{tabular}{|c|c|c|c|c|c|c|c|c|}
\hline $\begin{array}{l}\text { Fitzsimmons, } \\
2001\end{array}$ & USA & Long-term facility & GDS-S & RCT & 39 & $\begin{array}{l}\text { Small-group socialization } \\
\text { and recreational } \\
\text { bicycle therapy vs. } \\
\text { wait-list control }\end{array}$ & $\begin{array}{l}2 \text { weeks, } 560 \\
\text { min sessions } \\
\text { per week }\end{array}$ & $\begin{array}{l}\text { Mean GDS score } \\
\text { decreased significantly } \\
\text { from } 7.68 \text { to } 4.21 ; \\
\text { scores did not change } \\
\text { in control group }\end{array}$ \\
\hline $\begin{array}{l}\text { Hyer et al., } \\
2008\end{array}$ & USA & $\begin{array}{l}\text { Veteran's nursing } \\
\text { home }\end{array}$ & $\begin{array}{l}\text { GDS-S, LSI-Z, } \\
\text { MMSE }\end{array}$ & RCT & 25 & $\begin{array}{l}\text { CBT; } 2 \text { trials (1) initial } \\
\text { trial where group, } \\
\text { individual, and staff } \\
\text { therapy (GIST) vs. } \\
\text { treatment as usual } \\
\text { (TAU) and (2) the } \\
\text { continuation trial, } \\
\text { where the GIST group } \\
\text { remained and the TAU } \\
\text { group crossed over to } \\
\text { GIST }\end{array}$ & $\begin{array}{l}\text { Initial trial } \\
\text { consisted of } \\
15 \text { sessions } \\
\text { (up to } 2 \\
\text { individuals } \\
\text { and } 13 \text { groups } \\
\text { sessions), the } \\
\text { continuation } \\
\text { trial consisted } \\
\text { of } 14 \text { sessions } \\
\text { (absent the } \\
\text { initial } \\
\text { individual } \\
\text { session) }\end{array}$ & $\begin{array}{l}\text { Significant differences } \\
\text { between GIST and } \\
\text { TAU in favour of } \\
\text { GIST on the GDS-S } \\
\text { and LSI-Z after the } \\
\text { initial trial. } \\
\text { The GIST group } \\
\text { maintained } \\
\text { improvements after the } \\
\text { continuation trails. } \\
\text { After crossover to GIST, } \\
\text { TAU group showed } \\
\text { significant } \\
\text { improvement in } \\
\text { GDS-S. }\end{array}$ \\
\hline $\begin{array}{l}\text { Jordan et al., } \\
2009\end{array}$ & Australia & $\begin{array}{l}\text { Residential aged } \\
\text { care facility }\end{array}$ & $\begin{array}{l}\text { CMAI, CSDD, } \\
\text { PAS }\end{array}$ & $\begin{array}{l}\text { Controlled } \\
\text { experi- } \\
\text { mental }\end{array}$ & $\begin{array}{l}\text { Staff }=93, \\
\text { residents } \\
=45, \\
\text { family re- } \\
\text { members } \\
=33\end{array}$ & $\begin{array}{l}\text { Multiple intervention, } \\
\text { consisting of staff } \\
\text { depression training } \\
\text { program, three } \\
\text { interventions targeted } \\
\text { at residents (key } \\
\text { worker, life story book, } \\
\text { walking and talking } \\
\text { program) }\end{array}$ & $\begin{array}{l}\text { Training } \\
\text { program: } \\
\text { eight sessions } \\
\text { ranging from } \\
1.5 \text { to } 2 \text { hours } \\
\text { Three residents } \\
\text { interventions: } \\
12 \text { weeks }\end{array}$ & $\begin{array}{l}\text { The training program } \\
\text { was positive received } \\
\text { by the staff. } \\
\text { Staff knowledge and } \\
\text { self-efficacy have } \\
\text { increased significantly } \\
\text { for the treatment group } \\
\text { and maintained over } \\
\text { time. } \\
\text { There were more positive } \\
\text { feelings and reactions } \\
\text { to entering the } \\
\text { residential facilities } \\
\text { among residents four } \\
\text { to six months following } \\
\text { entry in the treatment } \\
\text { group. }\end{array}$ \\
\hline
\end{tabular}




\begin{tabular}{|c|c|c|c|c|c|c|c|c|}
\hline $\begin{array}{l}\text { AUTHOR, } \\
\text { YEAR }\end{array}$ & COUNTRY & SETTING & MEASURES & DESIGN & $\mathrm{N}$ & TREATMENT(S) & LENGTH & RESULT \\
\hline $\begin{array}{l}\text { Llewellyn- } \\
\text { Jones et al., } \\
1999\end{array}$ & Australia & $\begin{array}{l}\text { Residential care } \\
\text { facility }\end{array}$ & GDS & RCT & 169 & $\begin{array}{l}\text { "Shared care } \\
\text { intervention" public } \\
\text { health approach aimed } \\
\text { at improving detection, } \\
\text { self-referral, and access } \\
\text { to treatment services } \\
\text { vs. usual care }\end{array}$ & $\begin{array}{l}\text { Mean interval between } \\
\text { baseline and follow up } \\
\text { was } 40.9 \text { weeks }\end{array}$ & $\begin{array}{l}\text { GDS scores lower in } \\
\text { intervention group by } \\
\text { an average of } 1.42 \\
\text { points }\end{array}$ \\
\hline $\begin{array}{l}\text { McCurren } \\
\text { et al., } 1999\end{array}$ & USA & $\begin{array}{l}\text { Nursing home } \\
\text { facility }\end{array}$ & GDS & $\begin{array}{l}\text { Randomized } \\
\text { trial }\end{array}$ & 85 & $\begin{array}{l}\text { Individual psychotherapy } \\
\text { and paraprofessional } \\
\text { visits; individualized, } \\
\text { unstandardized } \\
\text { intervention that } \\
\text { included encouraging } \\
\text { behavioral activation } \\
\text { and social engagement } \\
\text { vs. usual care }\end{array}$ & $\begin{array}{l}24 \text { weeks, } 2 \text { visits per } \\
\text { week by volunteer, } 1 \\
\text { visit per week by nurse }\end{array}$ & $\begin{array}{l}\text { GDS decreased } \\
\text { significantly in } \\
\text { intervention group, not } \\
\text { in control group }\end{array}$ \\
\hline $\begin{array}{l}\text { Meeks and } \\
\text { Depp, } 2003\end{array}$ & USA & Nursing homes & $\begin{array}{l}\text { SADS, GAS, } \\
\text { HDRS, GDS, } \\
\text { MMSE }\end{array}$ & RCT & 20 & $\begin{array}{l}\text { Individual behavioral } \\
\text { therapy, pleasant event } \\
\text { behavioral intervention } \\
\text { vs. treatment as usual }\end{array}$ & $\begin{array}{l}10 \text { weeks ( } 6 \text { weeks active } \\
\text { treatment and } 4 \text { weeks } \\
\text { maintenance), one } \\
\text { session per week }\end{array}$ & $\begin{array}{l}\text { The treatment led to } \\
\text { increased activity level } \\
\text { and improvement in } \\
\text { diagnosis of } \\
\text { depression. }\end{array}$ \\
\hline $\begin{array}{l}\text { Rosen et al., } \\
\quad 2000\end{array}$ & USA & $\begin{array}{l}\text { Center for Jewish } \\
\text { Seniors }\end{array}$ & $\begin{array}{l}\text { MMSE, GAS, } \\
\text { HDRS, the } \\
\text { UKU side effect } \\
\text { rating scale }\end{array}$ & Experimental & 12 & Medication-sertraline & $\begin{array}{l}6 \text { weeks, residents started } \\
\text { on } 50 \mathrm{mg} / \text { day and } 4 \\
\text { weeks later, the } \\
\text { psychiatrist reviewed } \\
\text { the residents with an } \\
\text { option of increasing the } \\
\text { dose to } 100 \mathrm{mg} / \text { day for } \\
\text { the final } 2 \text { weeks }\end{array}$ & $\begin{array}{l}\text { All residents tolerated } \\
\text { their medication } \\
\text { without any significant } \\
\text { side effects. The } \\
\text { HDRS and GAS scores } \\
\text { improved significantly } \\
\text { and } 75 \% \text { of the } \\
\text { residents met criteria } \\
\text { for 'remission'. }\end{array}$ \\
\hline $\begin{array}{l}\text { Tsai et al., } \\
2008\end{array}$ & Taiwan & Nursing home & $\begin{array}{l}\text { GDS, MMSE, the } \\
\text { Barthel Index }\end{array}$ & $\begin{array}{l}\text { Quasi- } \\
\text { experimental }\end{array}$ & 63 & $\begin{array}{l}\text { Self-administered } \\
\text { self-worth therapy and } \\
\text { dignity therapy vs. } \\
\text { non-treatment control }\end{array}$ & $\begin{array}{l}4 \text { weeks, one } 30 \text {-minute } \\
\text { session per week }\end{array}$ & $\begin{array}{l}\text { Depressive symptoms at } \\
\text { 2-month follow-up } \\
\text { were more effectively } \\
\text { decreased in the } \\
\text { experimental group } \\
\text { than in the control } \\
\text { group }\end{array}$ \\
\hline
\end{tabular}




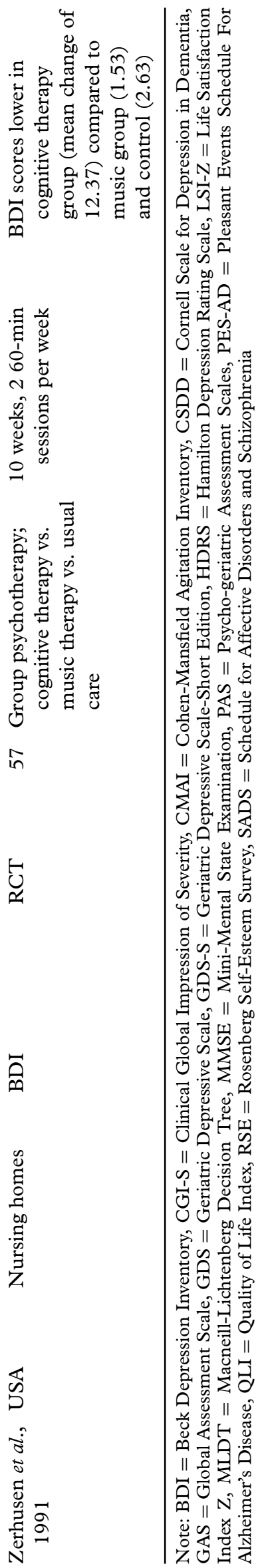

Psychiatry, 2003; Morris, 2008). However, no recent studies have systematically investigated the possible benefits of such a combined approach.

Over the past 12 years there has been increasing interest in multifaceted approaches to the treatment of depressed residents (Llewellyn-Jones et al., 1999; 2001; Brooker and Woolley, 2007; Brooker et al., 2007; Hyer et al., 2008; Jordan et al., 2009). For example, the multifaceted shared care intervention used by Llewellyn-Jones et al. (1999) included: (a) multidisciplinary consultation and collaboration to remove barriers to care, (b) training of GPs and carers in detection and management of depression, (c) depressionrelated health education and activity programs for residents. Similarly the British Enriched Opportunities program (Brooker and Woolley, 2007; Brooker et al., 2007) included individualized assessment of residents, case work, an activity and occupation program, staff training, management and leadership. These studies reported significant improvement in residents' depression and suggest that integrating multiple modalities should be the focus of future research.

As discussed above, it can be difficult to identify depressed residents. It is also challenging to treat them effectively. Some antidepressants, such as selective serotonin reuptake inhibitors (SSRIs), may have limited efficacy in residents with comorbid dementia (Burrows et al., 2002). In addition, some residents may not be able to participate effectively in psychotherapy because of their limited cognitive function (Kallenbach and Rigler, 2006; Carlson and Snowden, 2007).

There are important methodological limitations in many treatment studies. These include small sample sizes (Bharucha et al., 2006), variable study inclusion criteria (Snowden et al., 2003; Hyer et al., 2005), short treatment duration (Hyer et al., 2005), few randomized controlled trials (Carlson and Snowden, 2007) and heterogeneous outcome measures (Bharucha et al., 2006). However, these studies do provide strong evidence that depression is treatable in nursing home residents (Hyer et al., 2005).

\section{Issues in treatment of depression}

In spite of the evidence that depression is treatable in residential homes, many studies have found that depression is under-treated in this group (Masand, 1995; Hyer et al., 2005). About $50 \%$, or even up to $75 \%$ of residents with depression were receiving no treatment at all (Rovner et al., 1991; George et al., 2007).

Although there is evidence that the initiation of treatment for depression has improved in recent 
years (Boyle et al., 2004), the treatment is often inadequate or inappropriate. First, there is a reliance on antidepressants and very few residents receive non-pharmacological treatment for depression (George et al., 2007; Choi et al., 2009). Second, many residents receiving antidepressants are on sub-therapeutic doses (Draper et al., 2001; Brown et al., 2002). There is also evidence that antidepressants are rarely reviewed by physicians (O'Connor et al., 2010). Given these problems, it is not surprising that only a minority of residents on antidepressants show improvements in depressive symptoms (Draper et al., 2001; Boyle et al., 2004). The findings of inadequate treatment of depression in residential care homes have major implications for the management of depression in these environments. Many researchers have suggested that the management should go beyond first generation problems, such as identification and initial treatment, to include second generation problems, such as strategies for partial- and non-responders, and ongoing management through the maintenance phases (Draper et al., 2001; Datto et al., 2002; Weintraub et al., 2002; Boyle et al., 2004; Carlson and Snowden, 2007).

\section{Outcome and prognosis of depression in residential care homes}

As discussed in the etiology section, there is a bi-directional relationship between depression and risk factors for depression. Depression in residential homes is linked to poor physical health, decreased functional and cognitive abilities, pain, and poor nutrition (Parmelee et al., 1991; 1992a; Anstey et al., 2007; Smoliner et al., 2009). Depressed residents also have lower levels of social engagement (Achterberg et al., 2003; Tsai et al., 2009), more behavioral and vocal disturbance (Dwyer and Byrne, 2000; Brodaty et al., 2001), poorer quality of life (Smoliner et al., 2009) and increased use of health care services (Smalbrugge et al., 2006b).

The most alarming outcome of depression is that it is a significant risk factor for mortality in care home residents. Rovner et al. (1991) examined the relationship between depression and mortality in 454 nursing homes residents. The likelihood of death at one year was increased by $59 \%$ for residents with major depression compared to those with only depressive symptoms or no depression. Ashby et al. (1991) followed 973 care home residents for 8 to 16 months and found that depression was associated with increased mortality. In particular, depressed residents were three times more likely to die than those without depression or dementia. In the study by Parmelee et al. (1992a) of 898 nursing home and congregate apartment residents, the mortality rates were $33 \%$ for residents with major depression, $28 \%$ for residents with minor depression and $16 \%$ for non-depressed residents after 18 months. This result indicates a systematic and significant increase in mortality with increasing severity of depression. In one small study, the mortality rate for depressed residents reached $59 \%$ after four years (Ames, 1992).

These studies indicate that depression is associated with increased mortality in residential care homes for older people. However, there is controversy about the mechanism by which depression exerts its effect (Samuels and Katz, 1995). While some studies found that depression was an independent risk factor for mortality in residents (Rovner et al., 1991; Shah et al., 1993), others found no significant relationship between depression and mortality when demographic variables and correlates of depression, such as physical health, functional impairment, cognitive status, and history of depression, were taken into account (Parmelee et al., 1992a; Cuijpers, 2001). The different results might be due to methodological differences, such as the definition of depression, sampling strategies and the sample sizes, and more studies are needed for a clearer understanding of the relationship between depression and mortality among those who live in residential care homes.

There is evidence that much depression in residential care homes is chronic, with persistence rates ranging from $44 \%$ to $63 \%$. Sutcliffe et al. (2007) followed 308 newly admitted UK residents for nine months. Of the residents who were depressed at baseline, 44\% were still depressed after five and nine months. Similarly, Barca et al. (2010) reported a persistence rate of $45 \%$ after 12 months. Smalbrugge et al. (2006a) followed 350 Dutch nursing home residents for six months and reported a persistence rate of $63 \%$. This figure is similar to Ames et al. (1988), who found that of residents surviving after four years, $63 \%$ of previously depressed residents were still depressed and only $17 \%$ had recovered. Weyerer et al. (1995) followed 120 newly admitted residents (60 from residential care homes in the city of Mannheim Germany, and 60 from care homes in London, UK) for eight months. The prevalence of depression was high in both cities at admission $(35 \%$ in Mannheim and $48 \%$ in London) and did not change significantly over eight months. In both places, depression at baseline was the best predictor for depression three months and eight months later; sex, age, social isolation, ADLs, and cognitive impairment at the time of admission were not 
significantly associated with depression either three or eight months later.

The persistence rate seems to be lower for depressed residents with dementia. Payne et al. (2002) followed 201 residents with cognitive impairment. They found that at six months, only $15 \%$ of the depressed residents were still depressed, and at 12 months only $7.5 \%$ were depressed. The study suggested that the decline in depression over the year after admission likely reflects appropriate diagnosis and treatment of depression in residential care homes.

Depression might also be a risk factor for suicide in residents (Reiss and Tishler, 2008). A study in Finland found that 12 nursing home residents died by suicide in a 12-month period, accounting for $0.9 \%$ of all suicides in Finland in that year. Nine $(75 \%)$ of them were diagnosed with a depressive syndrome, although only three (33\%) were recognized by staff as having depressive symptoms before their death (Suominen et al., 2003).

It is important to point out that there are as yet relatively few outcome studies of depression in residential homes and most of those studies have short follow-up periods (Llewellyn-Jones and Snowdon, 2007). More longitudinal studies are needed for a better understanding of the outcomes of depression in residential care homes.

\section{Conclusion and recommendations for action}

Despite increased detection and treatment of depression in recent years (Boyle et al., 2004), depression remains a significant problem for older people living in residential homes (Snowdon, 2010). Prevalence remains high and the few longitudinal studies that have been conducted show high persistence of depression over time. Care staff still lack knowledge and understanding of depression with many seeing depression as a normal phenomenon for older people (Ayalon et al., 2008). Depression is therefore often not detected or treated. This lack of detection and treatment may have serious consequences, as depression does not often remit spontaneously in these home residents (Smalbrugge et al., 2006a; Barca et al., 2010) and is a significant risk factor for mortality (Ashby et al., 1991; Rovner et al., 1991; Shah et al., 1993), and suicide (Suominen et al., 2003). Detection is the essential first step in initiating assessment and treatment for depression.

Further research is needed to investigate those treatment approaches that appear promising, particularly multifaceted (Llewellyn-Jones et al., 1999) and psychosocial approaches (Snowden et al., 2003; Hyer et al., 2005). There is also a need for more longitudinal studies to inform us about incidence, persistence and outcomes of depression.

In clinical practice, there is a need for education of care staff (particularly personal carers) to ensure they understand that depression is a serious and treatable condition and that they recognize depressive symptoms and signs. Screening for depression should be mandatory in all residential care homes and linked to a process for referral and initiation of assessment and treatment. Finally, residential care homes could address environmental factors associated with depression, such as lack of privacy, and institute interventions known to benefit people with depression, such as recreational activities, for all residents as preventive measures for depression.

The devotion of an entire issue of International Psychogeriatrics (volume 22, issue 7 ) to the topic of mental health issues in long-term care homes, and the existence of the International Psychogeriatric Association's Task Force on Mental Health Services in Long-term Care Homes (Conn and Snowdon, 2010) indicate both the importance of depression in this setting as well as a determination to do something about it. However, a quarter of a century after one of us commenced a doctoral project which focused on the treatment of depression in residential care (Ames, 1990), the situation for many depressed residents around the world is still far from satisfactory and much work remains to be done, not least in ensuring the translation of existing knowledge into routine practice.

\section{Conflict of interest}

None.

\section{Description of authors' roles}

All five authors collaborated closely in reviewing the literature, and writing and revising this guest editorial.

Briony Dow, ${ }^{1}$ Xiaoping Lin, ${ }^{1}$ JeAN Tinney, ${ }^{1}$ Betty Haralambous ${ }^{1}$ and David Ames ${ }^{1}, 2$

${ }^{1}$ National Ageing Research Institute, Parkville, Victoria, Australia

${ }^{2}$ University of Melbourne Academic Unit for Psychiatry of

Old Age, Kew, Victoria, Australia

Email: b.dow@nari.unimelb.edu.au

\section{References}

Achterberg, W., Pot, A. M., Kerkstra, A., Ooms, M., Muller, M. and Ribbe, M. (2003). The effect of 
depression on social engagement in newly admitted Dutch nursing home residents. The Gerontologist, 43, 213-218.

Alexopoulos, G. S., Abrams, R. C., Young, R. C. and Shamoian, C. A. (1988). Cornell Scale for depression in dementia. Biological Psychiatry, 23, 271-284.

American Geriatrics Society and American Association for Geriatric Psychiatry (2003). Consensus statement on improving the quality of mental health care in US nursing homes: management of depression and behavioral symptoms associated with dementia. Fournal of the American Geriatrics Society, 51, 1287-1298.

American Psychiatric Association (1994). DSM-IV: Diagnostic and Statistical Manual of Mental Disorders, 4th edn. Washington, DC: American Psychiatric Association.

Ames, D. (1990). Depression among elderly residents in local authority homes for the elderly: its nature and the efficacy of intervention. British fournal of Psychiatry, 156, 667-675.

Ames, D. (1992). Psychiatric diagnoses made by the AGECAT system in residents of local authority homes for the elderly: outcome and diagnostic stability after four years. International fournal of Geriatric Psychiatry, 7, 83-87.

Ames, D. (1993). Depressive disorders among elderly people in long-term institutional care. Australian and New Zealand Fournal of Psychiatry, 27, 379-391.

Ames, D., Ashby, D., Mann, A. H. and Graham, N. (1988). Psychiatric illness in elderly residents of Part III homes in one London borough: prognosis and review. Age and Ageing, 17, 249-256.

Anstey, K. J., von Sanden, C. A., Sargent-Cox, K. and Luszcz, M. A. (2007). Prevalence and risk factors for depression in a longitudinal, population-based study including individuals in the community and residential care. American fournal of Geriatric Psychiatry, 15, 497-505.

Asghari, A., Ghaderi, N. and Ashory, A. (2006). The prevalence of pain among residents of nursing homes and the impact of pain on their mood and quality of life. Archives of Iranian Medicine, 9, 368-373.

Ashby, D., Ames, D., West, C. R., MacDonald, A., Graham, N. and Mann, A. H. (1991). Psychiatric morbidity as predictor of mortality for residents of local authority homes for the elderly. International fournal of Geriatric Psychiatry, 6, 567-575.

Australian Institute of Health and Welfare (AIHW) (2010). Residential Aged Care in Australia 2008-09: A Statistical Overview. Canberra: Australian Institute of Health and Welfare.

Ayalon, L., Arean, P. and Bornfeld, H. (2008). Correlates of knowledge and beliefs about depression among long-term care staff. International fournal of Geriatric Psychiatry, 23, 356-363.

Bagley, H. et al. (2000). Recognition of depression by staff in nursing and residential homes. Fournal of Clinical Nursing, 9, 445-450.

Baldwin, R. (2008). Mood disorders: depressive disorders. In R. Jacoby, C. Oppenheimer, T. Dening and A. Thomas (eds.), Oxford Textbook of Old Age Psychiatry (pp. 529-556). Oxford: Oxford University Press.

Banazak, D. A., Mullan, P. B., Gardiner, J. C. and Rajagopalan, S. (1999). Practice guidelines and late-life depression assessment in long-term care. Fournal of General Internal Medicine, 14, 438-440.
Barca, M. L., Engedal, K., Laks, J. and Selbaek, G. (2010). A 12 months' follow-up study of depression among nursing-home patients in Norway. Fournal of Affective Disorders, 120, 141-148.

Bell, M. and Goss, A. J. (2001). Recognition, assessment and treatment of depression in geriatric nursing home residents. Clinical Excellence for Nurse Practitioners, 5, 26-36.

Bharucha, A., Dew, M., Miller, M., Borson, S. and Reynolds, C. (2006). Psychotherapy in long-term care: a review. Fournal of the American Medical Directors Association, 7, 568-580.

Boyle, V. L., Roychoudhury, C., Beniak, R., Cohn, L., Bayer, A. and Katz, I. (2004). Recognition and management of depression in skilled-nursing and long-term care settings: evolving targets for quality improvement. American fournal of Geriatric Psychiatry, 12, 288-295.

Brodaty, H. et al. (2001). Psychosis, depression and behavioural disturbances in Sydney nursing home residents: prevalence and predictors. International fournal of Geriatric Psychiatry, 16, 504-512.

Brooker, D. and Woolley, R. (2007). Enriching opportunities for people living with dementia: The development of a blueprint for a sustainable activity-based model. Aging and Mental Health, 11, 371-383.

Brooker, D., Woolley, R. and Lee, D. (2007). Enriching opportunities for people living with dementia in nursing homes: an evaluation of a multi-level activity-based model of care. Aging and Mental Health, 11, 361-370.

Brown, E., Raue, P., Schulberg, H. and Bruce, $M$. (2006). Clinical competencies: caring for late-life depression in home care patients. Fournal of Gerontological Nursing, 32, 10-14.

Brown, M. N., Lapane, K. L. and Luisi, A. F. (2002). The management of depression in older nursing home residents. Fournal of the American Geriatrics Society, 50, 69-76.

Brühl, K. G., Hendrika, J. L. and Martien, T. M. (2007). Nurses' and nursing assistants' recognition of depression in elderly who depend on long-term care. Fournal of the American Medical Directors Association, 8, 441-445.

Buettner, L. L. and Fitzsimmons, S. (2002). AD-venture program: therapeutic biking for the treatment of depression in long-term care residents with dementia. American fournal of Alzheimer's Disease and Other Dementias, 17, 121-127.

Burrows, A. B. (1995). Depression in a long-term care facility: clinical features and discordance between nursing assessment and patient interviews. Fournal of the American Geriatrics Society, 43, 1118-1122.

Burrows, A., Morris, J., Simon, S., Hirdes, J. and Phillips, C. (2000). Development of a minimum data set-based depression rating scale for use in nursing homes. Age and Ageing, 29, 165-172.

Burrows, A. B., Salzman, C., Satlin, A., Noble, K., Pollock, B. G. and Gersh, T. (2002). A randomized, placebo-controlled trial of paroxetine in nursing home residents with non-major depression. Depression and Anxiety, 15, 102-110.

Carlson, W. L. and Snowden, M. (2007). Improving treatment for depression in the nursing home population: integrating the model of the depression care manager. Harvard Review of Psychiatry, 15, 128-132. 
Cataldo, J. K. (1994). Hardiness and death attitudes: predictors of depression in the institutionalized elderly. Archives of Psychiatric Nursing, 8, 326-332.

Cernin, P. A. and Lichtenberg, P. A. (2009). Behavioural treatment for depressed mood: a pleasant events intervention for seniors residing is assisted living. Clinical Gerontologist, 32, 324-331.

Chao, S.-Y. et al. (2006). The effects of group reminiscence therapy on depression, self esteem, and life satisfaction of elderly nursing home residents. Fournal of Nursing Research, $14,36-45$.

Choi, N. G., Ransom, S. and Wyllie, R. J. (2008). Depression in older nursing home residents: the influence of nursing home environmental stressors, coping, and acceptance of group and individual therapy. Aging and Mental Health, 12, 536-547.

Choi, N. G., Wyllie, R. J. and Ransom, S. (2009). Risk factors and intervention programs for depression in nursing home residents: nursing home staff interview findings. fournal of Gerontological Social Work, 52, 668-685.

Chow, E. S. L. et al. (2004). The prevalence of depressive symptoms among elderly Chinese private nursing home residents in Hong Kong. International fournal of Geriatric Psychiatry, 19, 734-740.

Chung, S. (2008). Residential status and depression among Korean elderly people: a comparison between residents of nursing home and those based in the community. Health and Social Care in the Community, 16, 370-377.

Conn, D. and Snowdon, J. (2010). Optimizing mental health in long-term care homes. International Psychogeriatrics, 22, 1023-1024.

Cuijpers, P. (2001). Mortality and depressive symptoms in inhabitants of residential homes. International fournal of Geriatric Psychiatry, 16, 131-138.

Cuijpers, P. and Lammeren, P. V. (1999). Depressive symptoms in chronically ill elderly people in residential homes. Aging and Mental Health, 3, 221-226.

Datto, C. J., Oslin, D. W., Streim, J. E., Scheinthal, S. M., DiFilippo, S. and Katz, I. R. (2002). Pharmacologic treatment of depression in nursing home residents: a mental health services perspective. Fournal of Geriatric Psychiatry and Neurology, 15, 141-146.

Davidson, S., Koritsas, S., O'Connnor, D. W. and Clarke, D. (2006). The feasibility of a GP led screening intervention for depression among nursing home residents. International fournal of Geriatric Psychiatry, 21, 10261030.

de Bellis, A. and Williams, J. (2008). The Cornell Scale for Depression in Dementia in the context of the Australian Aged Care Funding Instrument: a literature review. Contemporary Nurse, 30, 20-31.

Draper, B. et al. (2001). Use of psychotropics in Sydney nursing homes: associations with depression, psychosis, and behavioral disturbances. International Psychogeriatrics, 13, 107-120.

Dwyer, M. and Byrne, G. J. A. (2000). Disruptive vocalization and depression in older nursing home residents. International Psychogeriatrics, 12, 463-471.

Eisses, A. M. H., Kluiter, H., Jongenelis, K., Pot, A. M., Beekman, A. T. F. and Ormel, J. (2004). Risk indicators of depression in residential homes. International fournal of Geriatric Psychiatry, 19, 634-640.
Fitzsimmons, S. (2001). Easy rider wheelchair biking: a nursing-recreation therapy clinical trial for the treatment of depression. Fournal of Gerontological Nursing, 27, 14-23.

Garavaglia, B. (2004). Avoiding drug-induced depression in nursing home residents. Nursing Homes: Long Term Care Management, 53, 110-111.

George, K., Davison, T. E., McCabe, M., Mellor, D. and Moore, K. (2007). Treatment of depression in low-level residential care facilities for the elderly. International Psychogeriatrics, 19, 1153-1160.

Gerety, M. B. et al. (1994). Performance of case-finding tools for depression in the nursing home: Influence of clinical and functional characteristics and selection of optimal threshold scores. Fournal of the American Geriatrics Society, 42, 1103-1109.

Glaister, J. A. and Blair, C. (2008). Improved education and training for nursing assistants: keys to promoting the mental health of nursing home residents. Issues in Mental Health Nursing, 29, 863-872.

Gruber-Baldini, A. L., Zimmerman, S., Boustani, M., Watson, L. C., Williams, C. S. and Reed, P. S. (2005). Characteristics associated with depression in long-term care residents with dementia. The Gerontologist, 45, 50-55.

Henderson, A. S., Korten, A. E., Jorm, A. F., Christensen, H., Mackinnon, A. J. and Scott, L. R. (1994). Are nursing homes depressing. The Lancet, 344, 1091.

Hyer, L., Carpenter, B., Bishmann, D. and Wu, H.-S. (2005). Depression in long-term care. Clinical Psychology: Science and Practice, 12, 280-299.

Hyer, L., Yeager, C. A., Hilton, N. and Sacks, A. (2008). Group, individual, and staff therapy: an efficient and effective cognitive behavioral therapy in long-term care. American fournal of Alzheimer's Disease and Other Dementias, 23, 528-539.

Jones, R. N., Marcantonio, E. R. and Rabinowitz, T. (2003). Prevalence and correlates of recognized depression in US nursing homes. Fournal of the American Geriatrics Society, 51, 1404.

Jones, R. et al. (2004). Measuring depression in nursing home residents with the MDS and GDS. The Gerontologist, $44,55-56$

Jongenelis, K. et al. (2005). Diagnostic accuracy of the original 30-item and shortened versions of the Geriatric Depression Scale in nursing home patients. International Fournal of Geriatric Psychiatry, 20, 1067-1074.

Jordan, F., Byrne, G. and Bushell, A. (2009). Improving Mental Health in Aged Care Facilities: A Feasibility Study. Lutwyche, Queensland: in partnership with GPpartners, Deakin University, beyondblue, University of Queensland and Carers Queensland (funded by the Australian Government Department of Health and Ageing).

Junginger, J., Phelan, E., Cherry, K. and Levy, J. (1993). Prevalence of psychopathology in elderly persons in nursing homes and in the community. Hospital Community Psychiatry, 44, 381-383.

Kallenbach, L. E. and Rigler, S. K. (2006). Identification and management of depression in nursing facility residents. Fournal of the American Medical Directors Association, 7, 448-455.

Kerber, C. S., Dyck, M. J., Culp, K. R. and Buckwalter, K. (2005). Comparing the Geriatric Depression Scale, 
Minimum Data Set, and Primary Care Provider Diagnosis for Depression in Rural Nursing Home Residents. Fournal of the American Psychiatric Nurses Association, 11, 269-275.

Koritsas, S., Davidson, S., Clarke, D. and O'Connor, D. (2006). Diagnosing and treating depressions in nursing home residents: challenges for GPs. Australian fournal of Primary Health, 12, 104-108.

Krach, P., DeVaney, S., DeTurk, C. and Zink, M. H. (1996). Functional status of the oldest-old in a home setting. Fournal of Advanced Nursing, 24, 456-464.

Lach, H., Chang, Y. and Edwards, D. (2010). Can older adults with dementia accurately report dementia using brief forms? Reliability and validity of the Geriatric Depression Scale. Fournal of Gerontological Nursing, 36, 30-37.

Leo, R. J., Sherry, C., DiMartino, S. and Karuza, J. (2002). Psychiatric consultation in the nursing home: referral patterns and recognition of depression. Fournal of Psychosomatic Research, 53, 783-787.

Lin, P.-C., Wang, H.-H. and Huang, H.-T. (2007). Depressive symptoms among older residents at nursing homes in Taiwan. Fournal of Clinical Nursing, 16, 1719-1725.

Llewellyn-Jones, R. H. and Snowdon, J. (2007). Depression in nursing homes: ensuring adequate treatment. CNS Drugs, 21, 627-640.

Llewellyn-Jones, R. H., Baikie, K. A., Smithers, H., Cohen, J., Snowdon, J. and Tennant, C. C. (1999). Multifaceted shared care intervention for late life depression in residential care: randomised controlled trial. BMF, 319, 676-682.

Llewellyn-Jones, R. H. et al. (2001). How to help depressed older people living in residential care: a multifaceted shared-care intervention for late life depression. International Psychogeriatrics, 13, 477-492.

Masand, P. S. (1995). Depression in long-term care facilities. Geriatrics, 50, S16-S24.

McCabe, M. P., Russo, S., Mellor, D., Davison, T. E. and George, K. (2008). Effectiveness of a training program for carers to recognize depression among older people. International fournal of Geriatric Psychiatry, 23, 1290-1296.

McCurren, C. (2002). Assessment for depression among nursing home elders: evaluation of the MDS mood assessment. Geriatric Nursing, 23, 103-108.

McCurren, C., Dowe, D., Rattle, D. and Looney, S. (1999). Depression among nursing home elders: Testing an intervention strategy. Applied Nursing Research, 12, 185-195.

McDougall, F. A., Matthews, F. E., Kvaal, K., Dewey, M. E. and Brayne, C. (2007). Prevalence and symptomatology of depression in older people living in institutions in England and Wales. Age and Ageing, 36, 562-568.

Meeks, S. (2004). Further evaluation of the MDS Depression Scale versus the Geriatric Depression Scale among nursing home residents. Fournal of Mental Health and Aging, 10, 325-335.

Meeks, S. and Depp, C. A. (2003). Pleasant events-based behavioral intervention for depression in nursing home residents: a conceptual and empirical foundation. Clinical Gerontologist, 25, 125-148.

Meeks, S., Looney, S., Haitsma, K. and Teri, L. (2008). BE-ACTIV: a staff-assisted behavioral intervention for depression in nursing homes. The Gerontologist, 48, 105-114.

Meeks, S., Shah, S. N. and Ramsey, S. K. (2009). The Pleasant Events Schedule - Nursing Home Version: a useful tool for behavioral interventions in long-term care. Aging and Mental Health, 13, 445-455.

Morris, C. (2008). Managing depression among older people in care homes. Nursing and Residential Care, 10, $145-148$.

Mozley, C. G. et al. (2000). Psychiatric symptomatology in elderly people admitted to nursing and residential homes. Aging and Mental Health, 4, 136-141.

National Nursing Homes Survey (2004). www.cdc.gov/ nchs/nnhs.htm; last accessed 6 January 2011.

O'Connor, D. W., Griffith, J. and McSweeney, K. (2010). Changes to psychotropic medications in the six months after admission to nursing homes in Melbourne, Australia. International Psychogeriatrics, 22, 1149-1153.

Owsley, C., McGwin, G., Jr., Scilley, K., Meek, G. C., Seker, D. and Dyer, A. (2007). Effect of refractive error correction on health-related quality of life and depression in older nursing home residents. Archives of Ophthalmology, 125, 1471-1477.

Parmelee, P., Katz, I. and Lawton, M. (1991). The relationship of pain to depression among instituitionalized aged. Fournal of Gerontology, 46, 15-21.

Parmelee, P. A., Katz, I. R. and Lawton, M. P. (1992a). Depression and mortality among institutionalized aged Fournal of Gerontology, 47, 3-10.

Parmelee, P. A., Katz, I. R. and Lawton, M. P. (1992b). Incidence of depression in long-term care settings. Fournal of Gerontology, 47, M189-M196.

Payne, J. L. et al. (2002). Incidence, prevalence, and outcomes of depression in residents of a long-term care facility with dementia. International fournal of Geriatric Psychiatry, 17, 247-253.

Plastow, N. A. (2006). Libraries of life: using life history books with depressed care home residents. Geriatric Nursing, 27, 217-221.

Pot, A. M., Deeg, D. J. H., Twisk, J. W. R., Beekman, A. T. F. and Zarit, S. H. (2005). The longitudinal relationship between the use of long-term care and depressive symptoms in older adults. The Gerontologist, 45, 359-369.

Reiss, N. S. and Tishler, C. L. (2008). Suicidality in nursing home residents. Part I: prevalence, risk factors, methods, assessment, and management. Professional Psychology: Research and Practice, 39, 264-270.

Ribbe, M.W. et al. (1997). Nursing homes in 10 nations: a comparison between countries and settings. Age and Ageing, 26, 3-12.

Rinaldi, P. et al. (2003). Validation of the five-item Geriatric Depression Scale in elderly subjects in three different settings. Fournal of the American Geriatrics Society, 51, 694-698.

Rosen, J., Mulsant, B. H. and Pollock, B. G. (2000). Sertraline in the treatment of minor depression in nursing home residents: a pilot study. International fournal of Geriatric Psychiatry, 15, 177-180.

Rovner, B. W. and Katz, I. R. (1993). Psychiatric disorders in the nursing home: a selective review of studies related to clinical care. International fournal of Geriatric Psychiatry, 8, 75-87. 
Rovner, B. W., German, P. S., Brant, L. J., Clark, R., Burton, L. and Folstein, M. F. (1991). Depression and mortality in nursing homes. $\mathcal{F A M A}, 265,993-996$.

Ruckdeschel, K. P. D., Thompson, R. P. D., Datto, C. J. M. D., Streim, J. E. M. D. and Katz, I. R. (2004). Using the Minimum Data Set 2.0 Mood Disturbance items as a self-report screening instrument for depression in nursing home residents. American fournal of Geriatric Psychiatry, 12, 43-49.

Samuels, S. C. and Katz, I. B. (1995). Depression in the nursing home. Psychiatric Annals, 25, 419-424.

Sandberg, O., Gustafson, Y., Brännström, B. and Bucht, G. (1998). Prevalence of dementia, delirium and psychiatric symptoms in various care settings for the elderly. Scandinavian fournal of Social Medicine, 26, 56-62.

Segal, D. L. (2005). Relationships of assertiveness, depression, and social support among older nursing home residents. Behavior Modification, 29, 689-695.

Seitz, D., Purandare, N. and Conn, D. (2010). Prevalence of psychiatric disorders among older adults in long-term care homes: a systematic review. International Psychogeriatrics, 22, 1025-1039.

Shah, A., Phongsathorn, V., George, C., Bielawska, C. and Katona, C. (1993). Does psychiatric morbidity predict mortality in continuing care geriatric inpatients? International fournal of Geriatric Psychiatry, 8, 255-259.

Sheehan, B., D'Souza, G., Nwe, T. and O'Malley, R. (2007). Are care homes depressing for people with dementia? International fournal of Geriatric Psychiatry, 22, 816-817.

Smalbrugge, M., Jongenelis, L., Pot, A. M., Eefsting, J. A., Ribbe, M. W. and Beekman, A. T. (2006a). Incidence and outcome of depressive symptoms in nursing home patients in the Netherlands. American fournal of Geriatric Psychiatry, 14, 1069-1076.

Smalbrugge, M., Pot, A. M., Jongenelis, L., Gundy, C. M., Beekman, A. T. F. and Eefsting, J. A. (2006b). The impact of depression and anxiety on well being, disability and use of health care services in nursing home patients. International fournal of Geriatric Psychiatry, 21, 325-332.

Smoliner, C., Norman, K., Wagner, K.-H., Hartig, W., Lochs, H. and Pirlich, M. (2009). Malnutrition and depression in the institutionalised elderly. British fournal of Nutrition, 102, 1663-1667.

Snowden, M., Sato, K. and Roy-Byrne, P. (2003). Assessment and treatment of nursing home residents with depression or behavioral symptoms associated with dementia: a review of the literature. Fournal of the American Geriatrics Society, 51, 1305-1317.

Snowdon, J. (2010). Depression in nursing homes. International Psychogeriatrics, 1143-1148.

Snowdon, J. and Purandare, N. (2010). Residential care for people with dementia. In: D. Ames, A. Burns and J. T. O'Brien (eds.), Dementia, 4th edition (pp. 266-274). London: Hodder Arnold.

Snowdon, J., Burgess, E., Vaughan, R. and Miller, R. (1996). Use of antidepressants and the prevalence of depression and cognitive impairment in Sydney nursing homes. International fournal of Geriatric Psychiatry, 11, 599-606.

Stout, I., Wilkin, D. and Jolley, D. J. (1993). Psychiatric morbidity among 'able' residents of part III homes. International fournal of Geriatric Psychiatry, 8, 949-952.
Suominen, K., Henriksson, M., Isometsä, E., Conwell, Y., Heilä, H. and Lönnqvist, J. (2003). Nursing home suicides: a psychological autopsy study. International Fournal of Geriatric Psychiatry, 18, 1095-1101.

Sutcliffe, C. et al. (2007). Depressed mood, cognitive impairment, and survival in older people admitted to care homes in England. American fournal of Geriatric Psychiatry 15, 708-715.

Teresi, J., Abrams, R., Holmes, D., Ramirez, M. and Eimicke, J. (2001). Prevalence of depression and depression recognition in nursing homes. Social Psychiatry and Psychiatric Epidemiology, 36, 613-620.

Tsai, Y.-F., Chung, J. W. Y., Wong, T. K. S. and Huang, C.-M. (2005). Comparison of the prevalence and risk factors for depressive symptoms among elderly nursing home residents in Taiwan and Hong Kong. International Fournal of Geriatric Psychiatry, 20, 315-321.

Tsai, Y.-F., Wong, T. K. S., Tsai, H.-H. and Ku, Y.-C. (2008). Self-worth therapy for depressive symptoms in older nursing home residents. Fournal of Advanced Nursing, 64, 488-494.

Tsai, C.-F. et al. (2009). Depression is the Strongest independent risk factor for poor social engagement among Chinese elderly veteran assisted-living residents. Fournal of the Chinese Medical Association, 72, 478-483.

Watson, L. C. et al. (2006). Depression in assisted living is common and related to physical burden. American fournal of Geriatric Psychiatry, 14, 876-883.

Watson, L. C., Zimmerman, S., Cohen, L. W. and Dominik, R. (2009). Practical depression screening in residential care/assisted living: five methods compared with gold standard diagnoses. American fournal of Geriatric Psychiatry, 17, 556-564.

Weintraub, D., Datto, C. J., Streim, J. E. and Katz, I. R. (2002). Second-generation issues in the management of depression in nursing homes. Fournal of the American Geriatrics Society, 50, 2100-2101.

Weyerer, S., Häfner, H., Mann, A. H., Ames, D. and Graham, N. (1995). Prevalence and course of depression among elderly residential home admissions in Mannheim and Camden London. International Psychogeriatrics, 7, 479-493.

Wittenberg, R., Comas-Herrera, A., Pickard, L. and Hancock, R. (2004). Future Demand for Long-term Care in the UK: A Summary of Projections of Long-Term Care Finance for Older People to 2051. York: Joseph Rowntree Foundation.

Wood, S., Cummings, J. L., Schnelle, B. and Stephens, M. (2002). A videotape-based training method for improving the detection of depression in residents of long-term care facilities. The Gerontologist, 42, 114-118.

World Health Organization (1992). International Classification of Diseases: 10th revision. Geneva: World Health Organization.

Zeiss, A. M. (2005). Depression in long-term care: contrasting a disease model with attention to environmental impact. Clinical Psychology: Science and Practice, 12, 300-302.

Zerhusen, J. D., Boyle, K. and Wilson, W. (1991). Out of the darkness: group cognitive therapy for depressed elderly. fournal of Psychosocial Nursing and Mental Health Services, 29, 16-21. 